\title{
Ecophysiological responses to drought followed by re-watering of two native Chilean swamp forest plants: Myrceugenia exsucca (DC.) 0 . Berg and Luma chequen (Molina) A. Gray
}

\author{
Respuestas ecofisiológicas a la sequía seguida de rehidratación en dos plantas \\ forestales nativas chilenas de pantano: Myrceugenia exsucca (DC.) O. Berg y Luma \\ chequen (Molina) A. Gray
}

\author{
luisa Bascuñán-Godoy ${ }^{1 *}$, Claudia Alcaíno ${ }^{1}$, Danny Eduardo Carvajal ${ }^{2}$, Carolina Sanhueza ${ }^{3}$, Sonia \\ MonTECINOS ${ }^{4}$ \& ANTONIO MALDONADO 1,5
}

\author{
${ }^{1}$ Centro de Estudios Avanzados en Zonas Áridas (CEAZA), Consorcio: Universidad de La Serena, INIA Intihuasi, Universidad \\ Católica del Norte, Casilla 599, Coquimbo, Chile. \\ 2Departamento de Biología, Facultad de Ciencias, Universidad de La Serena, Casilla 554, La Serena, Chile \\ ${ }^{3}$ Departamento de Botánica, Facultad de Ciencias Naturales y Oceanográficas, Universidad de Concepción, Casilla 160-C, \\ Correo 3, Concepción, Chile. \\ ${ }^{4}$ Departamento de Física, Facultad de Ciencias, Universidad de La Serena, Casilla 554, La Serena, Chile \\ ${ }^{5}$ Departamento de Biología Marina, Universidad Católica del Norte, Larrondo 1281, Coquimbo, Chile. \\ *luisa.bascunan@ceaza.cl
}

\begin{abstract}
Myrceugenia exsucca (DC.) O. Berg and Luma chequen (Molina) A. Gray are two predominant species of Myrtaceae from the swamp forest which are strongly threatened by destruction of their habitat. Conservation programs include the creation of new protected areas which often have different environmental conditions respect their natural habitat. The drought tolerance and the capability to restore their physiological performance after stress relief are characteristic of great importance for the successful conservation programs on these kinds of plants. Understanding how these plants respond to episodic drought and watering pulse was the principal aim of this work. In this sense, water relations, soluble sugars, pigments and photosystem II (PSII) performance were studied. In general the water relationships were less affected by drought in $L$. chequen than in $M$. exsucca which was consistent with a higher maintenance of photochemical quenching (qP) in the first one. In addition, L. chequen exhibited complete recovery of water potential and maximum PSII efficiency and increasing the proportion of photochemical processes and soluble sugars related with a higher photosynthetic recovery. Contrastingly, $M$. exsucca was unable to recover its water potential and the proportion of open reaction centers of PSII under re-watering indicating a lower capacity of recovery. These results shown different capabilities to cope and reestablish physiological performance after water scarcity episode between these two native chilean swamp forest plants. We hope that these results will be important for conservation and re-vegetation managements programs.
\end{abstract}

KEYwORDS: Myrtaceae, photosynthetic performance, water deficit, re-watering.

\section{RESUMEN}

Myrceugenia exsucca (DC.) O. Berg y Luma chequen (Molina) A. Gray son dos especies predominantes de Myrtaceae del bosque pantanoso que están fuertemente amenazadas por la destrucción de su hábitat. Los programas de conservación incluyen la creación de nuevas áreas protegidas que a menudo tienen diferentes condiciones ambientales respecto a su hábitat natural. La tolerancia a la sequía y la capacidad de recuperación son características de gran importancia en los programas de conservación en este tipo de plantas. Entender cómo estas plantas responden a la sequía y la rehidratación fue el objetivo principal de este trabajo. Por ende, se estudiaron las relaciones hídricas, azúcares solubles, pigmentos y rendimiento del fotosistema II (PSII). En general, el estado hídrico de $L$. chequen fue menos afectado que el de $M$. exsucca. Esto fue consistente con el mayor mantenimiento del apagamiento fotoquímico en $L$. chequen respecto a $M$. exsucca. Además, L. chequen exhibió una recuperación completa del potencial hídrico y de la máxima eficiencia PSII incrementando estadísticamente el apagamiento fotoquímico (qP), que podría relacionarse con el fuerte incremento en los azúcares solubles, indicando una mayor recuperación fotosintética. En contraste, M. exsucca fue incapaz de recuperar su potencial hídrico y la proporción de centros de reacción del PSII abiertos bajo condiciones de rehidratación 
indicando una menor capacidad de recuperación. Estos resultados muestran diferentes capacidades para hacer frente y restablecer el funcionamiento fisiológico después de un episodio de escasez hídrica entre estas dos plantas de pantano chilenas. Esperamos que estos resultados sean importantes para el éxito y gestiones de programas re-vegetación a favor de la conservación.

Palabras clave: Myrtaceae, desempeño fotosintético, déficit hídrico, rehidratación.

\section{INTRODUCTION}

Swamp forests are commonly located in groundwaterfed systems restricted to particular geomorphic settings and associated with a superficial phreatic water table (Correa-Araneda et al. 2012, Maldonado \& Villagrán 2001, Ramírez et al.1983). These isolated, discontinuous forests fulfill important ecological functions related to watercourse protection, biological diversity conservation, and erosion and flood control (Correa-Araneda et al. 2011, Solervicens \& Elgueta 1994). Myrcengenia exsucca (DC.) O.Berg (Myrtaceae) and Luma chequen (Molina) A. Gray (Myrtaceae) are two species of great importance in the swamp forest (San Martín et al. 1988, Bascuñán et al. 2013). These species show some microhabitat differences in their distribution. L. chequen is commonly found in lower moisture sites (Landrum 1988, Villagrán 1982) and is distributed across a north-south precipitation gradient from $30.5^{\circ} \mathrm{S}$ (Coquimbo, Coquimbo Region) to $42^{\circ} \mathrm{S}$ (Chiloe, Los Lagos Region), whereas $M$. exsucca is limited to watersaturated soils and is found between $32^{\circ} \mathrm{S}$ (Coquimbo, Coquimbo Region) and $44^{\circ} \mathrm{S}$ (Llanquihue, Los Lagos Region) (Landrum 1988, Villagrán 1982). The ecosystems inhabited by $M$. exsucca and $L$.chequen can flood 4-8 months a year, depending on the location in the precipitation gradient, with a phreatic layer reaching $2 \mathrm{~m}$ in depth during the winter in southern Chile (Ramírez et al. 1995).

However, when the standing water disappears in the summer, soil water content is $50-60 \%$ lower than in the winter (Correa-Araneda et al. 2012, Ramírez et al. 1983). Today the financial incentives, which permit the execution of drainage projects to increase the area suitable for agriculture or forestation, and the inter-annual variations, related to the El Niño-Southern Oscillation, could affect the depth of the water table, representing a serious threat to these swamp forest ecosystems (Aceituno 1988, Maldonado \& Villagrán 2001). In fact, M. exsucca is considered a vulnerable species because its presence is very limited and fragmented as a consequence of its habitat destruction principally in favor of agriculture (Arancio et al. 2001, Ramírez et al.1983). The creation of new protected areas as well as the development of conservation and management re-vegetation programs to help balance exploitation/conservation should be a high priority for these species (Arancio et al. 2001). In this context re-vegetation programs must have knowledge about the ecophysiological responses of native plants to different water levels and the capacity of recovery after a drought episode.

Many conservation studies have been carried out on Mediterranean plants with a higher water use economy, while physiological studies conducted on the drought performance of hydrophilic plants are still very scarce (Savage et al. 2009, Pagter et al. 2005, Nakai et al. 2010, Mielke \& Schaffer 2010).

Low water availability reduces photosynthesis principally due to stomatal closure and metabolic impairments (Lauteri et al. 2014, Hu et al. 2010, Chaves et al. 2009, Flexas \& Medrano 2002). Under these conditions, the light incident on the leaf surface largely exceeds the amount that can be used in photosynthesis (Demmig-Adams \& Adams 1992, Demmig-Adams et al. 1996). The excess energy absorbed can induce photoinhibition, a consequence of either reversible down-regulation of PSII through dissipation of excess absorbed energy as thermal dissipation (measured as NPQ) or irreversible inactivation of PSII and damage to the PSII reaction center protein (Peguero-Pina et al. 2009) when the rate of photodamage to PSII exceeds the rate of reparation (Nishiyama et al. 2011). It have been reported that the thermal dissipation is an important strategy under moderate drought conditions in L. chequen, but not in $M$. exsucca (BascuñánGodoy et al. 2013), however, combined responses to different intensities of drought and the capacity of recovery and the mechanisms underlying are relative lower studied.

We hypothesize that $L$. chequen is able to maintain a higher photochemical capacity under different intensities of drought which allow it a faster recovery after water stress relief compared with $M$. exsucca, which is a species strictly limited to saturated soils. In this sense, the principal aim of this work was to evaluate the effect of a drying and re/watering cycle on the photochemistry native Chilean swamp forest plants. Considering these mechanisms are important for the plant physiological performance under constraints environmental conditions we think that these findings could contribute to create management practices for these species and therefore to the success of restoration programs for native swamp forest plants.

\section{MATERIALS AND METHODS}

\section{Plant material and treatments}

One year old saplings of $M$. exsucca and $L$. chequen measuring $30 \mathrm{~cm}$ in height were obtained from a botanical 
garden (Talca University, VII Region, Chile). Saplings were maintained outdoors at the University of La Serena (IV Region, Chile) in 3 L plastic pots using a 1:1 mixture of soil: organic substrate, and watered regularly three times a week for one month. Three weeks before starting the experiment, plants were placed in a controlled growth chamber at $21^{\circ} \mathrm{C}$ with a photon flux density of about $300 \mu \mathrm{mol} \mathrm{m} \mathrm{m}^{-2}$ $\mathrm{s}^{-1}$ provided by sodium lamps (Son/T Agro 400W, Philips, Eindhoven, The Netherlands), a $12 \mathrm{~h}$ photoperiod, and $80 \%$ relative humidity. Plants were well- irrigated and supplied weekly with $50 \%$ Hoagland's solution prior to the onset of the experiment. To assess the physiological performance of the saplings, we established a complete randomized design. One group of six plants randomly selected for each species was kept as the control (C) and irrigated once a day to field capacity to obtain soil saturation. Two additional groups with the same number of randomly selected plants were utilized for mild (MiD, 4 days without irrigation) and moderate $(\mathrm{MoD}, 10$ days without irrigation) drought treatments. During $\mathrm{MiD}$ and $\mathrm{MoD}$, soil water content dropped to $60 \%$ and $40 \%$, respectively, relative to control conditions $(100 \%)$. These water conditions were chosen to reflect the water content of the soil where these plants grow during the summer. The MoD plants were then watered to soil saturation and measurements taken 1 day later. Samples for relative leaf water content, total soluble sugars, and pigments were taken at midday.

LEAF AREA, SPECIFIC LEAF AREA, AND PLANT WATER POTENTIAL The leaf area of 12 leaves per species was measured with an area meter (CI-400 Image Analysis Systems, USA). Each leaf came from a secondary branch of a different plant. Specific leaf area was calculated as the ratio of leaf area to leaf dry mass $\left(\mathrm{m}^{2} \mathrm{~kg}^{-1}\right)$. Leaf samples were dried for $48 \mathrm{~h}$ in an oven at $70^{\circ} \mathrm{C}$ to constant weight. Stem water potential $\left(\Psi_{w}\right)$ of six excised secondary branches per treatment was measured with a Scholander pressure chamber (Soil Moisture Equipment Corp., USA) at midday when the plants reach their minimum water potential. Relative leaf water content was calculated as follows: $\mathrm{RWC}=($ fresh weight - dry weight $/$ (turgid weight - dry weight $) \times 100$. The turgid leaf weight was determined after keeping the leaf in distilled water until it reached a constant weight (full turgor, typically after $12 \mathrm{~h}$ ) in darkness at $4{ }^{\circ} \mathrm{C}$ to minimize respiration loss. Leaf dry weight was obtained after keeping the turgid leaf for $48 \mathrm{~h}$ in an oven at $70^{\circ} \mathrm{C}$.

\section{TOTAL SOLUBLE SUGAR ANALYSIS}

Total soluble sugars (TSS) were extracted with ethanol $(90 \%)$ for $24 \mathrm{~h}$ from dry leaves of secondary branches of 4 individuals from both $M$. exsucca and $L$. chequen. The extracts were centrifuged at $12,000 \mathrm{~g}$ for $10 \mathrm{~min}$ and the supernatants used for the quantification of total soluble sugars according to the Resorcinol method, using glucose as the standard (Roe 1934). Six replicates per species and treatment were obtained from fully expanded leaves of different individuals.

\section{Chlorophylls And CARotenoids}

Chlorophyll (Chl) $a$ and $b$ and total carotenoids $(\mathrm{C}+\mathrm{x})$ were extracted with $90 \%$ ethanol from leaves of secondary branches of six individuals for each species and treatment. The extracts were centrifuged at $12,000 \mathrm{~g}$ for $10 \mathrm{~min}$ and absorbance was measured with a spectrophotometer at 663 , 646 and $470 \mathrm{~nm}$ for Chl $a$, Chl $b$, and total carotenoids, respectively, according to Lichtenthaler (1987).

Chlorophyll $a(\mu \mathrm{g} / \mathrm{ml})=12.21(\mathrm{~A} 663)-2.81$ (A646)

Chlorophyll $b(\mu \mathrm{g} / \mathrm{ml})=20.13(\mathrm{~A} 646)-5.03(\mathrm{~A} 663)$

Carotenoids $(\mu \mathrm{g} / \mathrm{ml})=(1000 \mathrm{~A} 470-3.27[\mathrm{chl} a]-104[\mathrm{chl}$ b])/227

\section{Chlorophyll a Fluorescence MEASUREMENTS}

Chlorophyll fluorescence measurements were performed early in the morning (9-11 h) using a portable fluorometer (FMS 2, Hansatech Instruments Ltd., Norfolk, UK). Leaves of secondary branches of six individuals from the different water treatments were dark-adapted for $30 \mathrm{~min}$ using the instrument leaf-clips to obtain open PSII centers to ensure maximum photochemical efficiency. Chlorophyll fluorescence recordings and calculations were performed by a pulse amplitude modulated fluorometer according to Schreiber et al. (1986). The fiber optic and its adapter were fixed to a ring located over the clip about $10 \mathrm{~mm}$ from the sample and the different light pulses (see below) were applied following the standard routines programmed within the instrument. All measurements were done with the same hardware configuration. Minimal fluorescence (Fo) with all PSII reaction centers in the open state was determined by applying a weak modulated light $\left(0.4 \mu \mathrm{mol} \mathrm{m}^{-2} \mathrm{~s}^{-1}\right)$. Maximal fluorescence $(\mathrm{Fm})$ with all PSII reaction centers in the closed state was induced by a $0.8 \mathrm{~s}$ saturating pulse of white light $\left(4500 \mu \mathrm{mol} \mathrm{m}^{-2} \mathrm{~s}^{-1}\right)$. After $10 \mathrm{~s}$, the actinic light of 300 $\mu \mathrm{mol} \mathrm{m} \mathrm{m}^{-2} \mathrm{~s}^{-1}$ was turned on, and the same saturating pulse described previously was applied every $20 \mathrm{~s}$ until steadystate photosynthesis was reached in order to obtain Fs and Fm. Finally, Fo' was measured after turning the actinic light off and applying a $2 \mathrm{~s}$ far red light pulse. Definitions of fluorescence parameters (qP, Fv/Fm, and ФPSII) were used as described by Maxwell \& Johnson (2000). Dark relaxation kinetics of NPQ were then resolved into fast relaxing (NPQf) and slow relaxing components (NPQs) according to Walters \& Horton (1991). Measurements were performed in six replicates per species and treatment and were randomly selected from different individuals during control, MiD, MoD and re-watering treatments.

STATISTICAL ANALYSIS

For all parameters, we used generalized linear models 
(GLMs, Crawley, 1993) to assess whether species and water treatments interacted to affect the physiological performance of the saplings. For this analysis, we used a Gaussian error distribution, and considered species and water treatments as the main factors, and the physiological parameters as the response variable. Multiple comparison procedures were carried out using the Dunnett test in the multcomp package. Statistical analysis was performed using the $\mathrm{R}$ statistical environment ( $\mathrm{R}$ Development Core Team 2012).

\section{RESULTS}

EFFECTS OF WATER TREATMENTS ON LEAF AREA, SPECIFIC LEAF AREA, PLANT WATER POTENTIAL, AND TOTAL SOLUBLE SUGARS The leaf area and specific leaf area did not vary with the water treatment (Table I). Statistical differences in leaf area $\left(\mathrm{F}_{1,10}=11.5, \mathrm{P}<0.007\right)$ and specific leaf area $(\mathrm{F} 1,10=11.1$, $\mathrm{P}<0.007$ ) were observed only between species (Table I). $\Psi_{\mathrm{w}}$ was statistically similar for species under control conditions (Fig. 1A). However, $\Psi_{\mathrm{w}}$ differed significantly for water treatments $\left(\mathrm{F}_{3,41}=32.24, \mathrm{P}<0.009\right)$, species $\left(\mathrm{F}_{1,44}=41.92\right.$, $\mathrm{P}<0.009$ ), and the interaction of treatment and species $\left(\mathrm{F}_{3,38}=4.93, \mathrm{P}<0.01\right)$. Under $\mathrm{MiD}, \Psi_{\mathrm{w}}$ for $M$. exsucca decreased significantly from -0.5 (under control conditions) to $-1.2 \mathrm{MPa}$, while values for $L$. chequen remained close to $-0.5 \mathrm{MPa}$. Under $\mathrm{MoD}$ conditions, the $\Psi_{\mathrm{w}}$ for both species decreased to similar values (approximately -1.5 MPa, Fig.1A). After watering was resumed (re-watering), the $\Psi_{\mathrm{w}}$ for $M$. exsucca was partially recovered, while that for $L$. chequen returned to control levels. Leaf RWC was significantly affected by water treatment $\left(\mathrm{F}_{3,40}=18.35\right.$, $\mathrm{P}<0.01)$ and by the interaction of water treatment and species $\left(\mathrm{F}_{3,37}=8.84, \mathrm{P}<0.01\right)$. RWC was similar under control conditions but significantly decreased under MoD conditions for both species (Fig.1B), with a reduction of $35 \%$ for $M$. exsucca and $12 \%$ for L. chequen. Despite the low RWC under MoD conditions, both species were able to recover their water status $24 \mathrm{~h}$ after re-watering, reaching values similar to those of control plants. Statistical differences in TSS were found for species $(\mathrm{F} 1,30=25.1$, $\mathrm{P}<0.01)$ and treatments $\left(\mathrm{F}_{3,27}=7.1, \mathrm{P}<0.01\right)$. L. chequen contained $31 \%$ more TSS than $M$. exsucca under control conditions (Fig.1C). However, the amount of TSS in response to $\mathrm{MiD}$ and $\mathrm{MoD}$ treatments was not affected in either M. exsucca or L. chequen. Nevertheless, $24 \mathrm{~h}$ after re-watering, L. chequen exhibited a statistically significant increase in TSS of approximately $40 \%$, with respect to control conditions.

EfFEcts of MiLd DROUGHT, MODERATE DROUGHT, AND REWATERING ON CHLOROPHYLL FLUORESCENCE PARAMETERS

Fv/Fm values were optimal in both species $(\sim 0.8)$ under control conditions (Fig.2A), although different water treatments significantly affected this response $\left(\mathrm{F}_{3,37}=4.87\right.$, $\mathrm{P}<0.05)$. M. exsucca was able to maintain its Fv/Fm during the water deficit treatments (MiD and MoD). On the other hand, L. chequen was only able to maintain its Fv/Fm during MiD and exhibited a 10\% decrease during MoD. Notwithstanding, L. chequen was able to recover its Fv/Fm to initial values after re-watering. Quantum yield of PSII (ФPSII) responses were dependent on species $\left(\mathrm{F}_{1,40}=16.92\right.$, $\mathrm{P}<0.01)$ and treatment $\left(\mathrm{F}_{3,37}=3.97, \mathrm{P}=0.02\right)$. ФPSII was $46 \%$ higher in $M$. exsucca than in L. chequen under control conditions (Fig. 2B). However, under MiD conditions, ФPSII for $M$. exsucca decreased by $31 \%$, reaching values similar to those for L. chequen (Fig. 2B). The proportion of open reaction centers of PSII ( $\mathrm{qP}$ ) varied according

TABLE I. Effect of progressive drought and re-watering on leaf area $\left(\mathrm{cm}^{2}\right)$ and specific leaf area $\left(\mathrm{m}^{2} \mathrm{~kg}^{-1}\right)$ of $M$. exsucca and $L$. chequen. Results show mean values \pm SE of 6 replicates from different individuals. Different letters represent significant differences between treatment and species $\mathrm{P}<0.05$ using Dunnett test.

TABla I. Efecto de un tratamiento de sequía progresiva y rehidratación en el área foliar $\left(\mathrm{cm}^{2}\right)$ y el área foliar específica $\left(\mathrm{m}^{2} \mathrm{~kg} \mathrm{~g}^{-1}\right) \mathrm{de} M$. exsucca y L. chequen. Los resultados muestran valores promedios $\pm \mathrm{SE}$ de 6 réplicas de individuos diferentes. Letras distintas representan diferencias significativas entre el tratamiento y la especie $\mathrm{P}<0,05$, utilizando la prueba de Dunnett.

\begin{tabular}{llcc}
\hline & & LeAf AREA $\left(\mathrm{cm}^{2}\right)$ & SPeCific LeAf AREA $\left(\mathrm{m}^{2} \mathrm{~kg}^{-1}\right)$ \\
\hline M. exsucca & $\mathrm{C}$ & $2.9 \pm 0.3(\mathrm{a})$ & $8.6 \pm 0.6(\mathrm{~b})$ \\
& $\mathrm{MiD}$ & $2.8 \pm 0.4(\mathrm{a})$ & $10 \pm 0.8(\mathrm{~b})$ \\
& $\mathrm{MoD}$ & $2.7 \pm 0.5(\mathrm{a})$ & $8.4 \pm 1(\mathrm{~b})$ \\
& $\mathrm{Rw}$ & $2.9 \pm 0.3(\mathrm{a})$ & $8.6 \pm 0.4(\mathrm{~b})$ \\
L. chequen & $\mathrm{C}$ & $1.4 \pm 0.3(\mathrm{~b})$ & $12 \pm 0.7(\mathrm{a})$ \\
& $\mathrm{MiD}$ & $1.2 \pm 0.4(\mathrm{~b})$ & $12 \pm 0.5(\mathrm{ab})$ \\
& $\mathrm{MoD}$ & $1.4 \pm 0.2(\mathrm{~b})$ & $13 \pm 0.8(\mathrm{a})$ \\
& $\mathrm{Rw}$ & $1.3 \pm 0.1(\mathrm{~b})$ & $13 \pm 0.4(\mathrm{a})$ \\
\hline
\end{tabular}




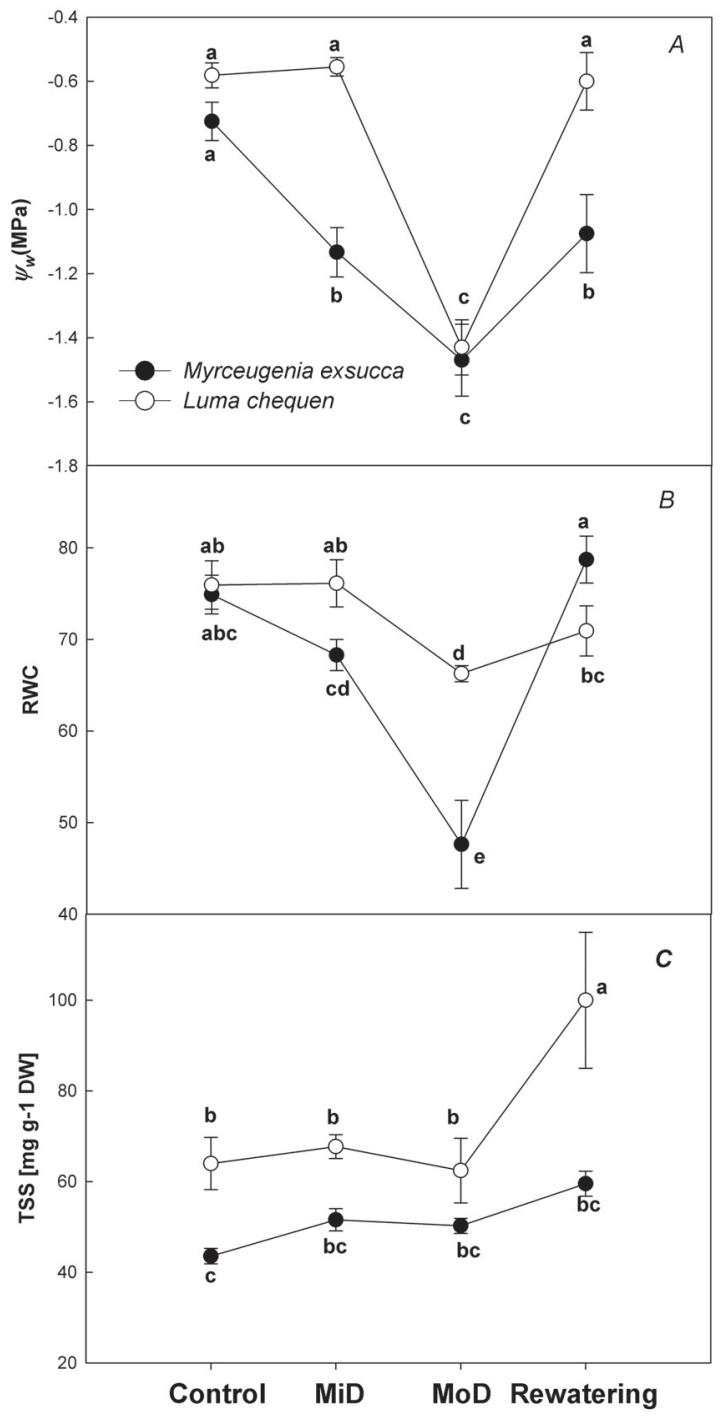

FIGURE 1. (A) Water potential $\left(\Psi_{\mathrm{w}}\right)$, (B) relative water content (RWC) and (C) total soluble sugars (TSS) of leaves under different irrigation treatments. Control, mild drought (MiD), moderate drought $(\mathrm{MoD})$ and re-watering. Values represent mean \pm standard error of six replicates from different individuals. Different letters denote statistical differences by Dunnett test $(\mathrm{P}<0.05)$ among treatments and species.

Figura 1. (A) Potencial hídrico $\left(\Psi_{w}\right)$, (B) contenido relativo de agua (RWC) y (C) azúcares solubles totales (TSS) de las hojas bajo diferentes tratamientos de riego. Control, sequía leve (MID), sequía moderada $(\mathrm{MoD})$ y re-hidratación. Los valores representan el promedio \pm error estándar de seis repeticiones de diferentes individuos. Letras diferentes indican diferencias estadísticas según la prueba de Dunnett $(\mathrm{P}<0,05)$ entre los tratamientos y las especies.

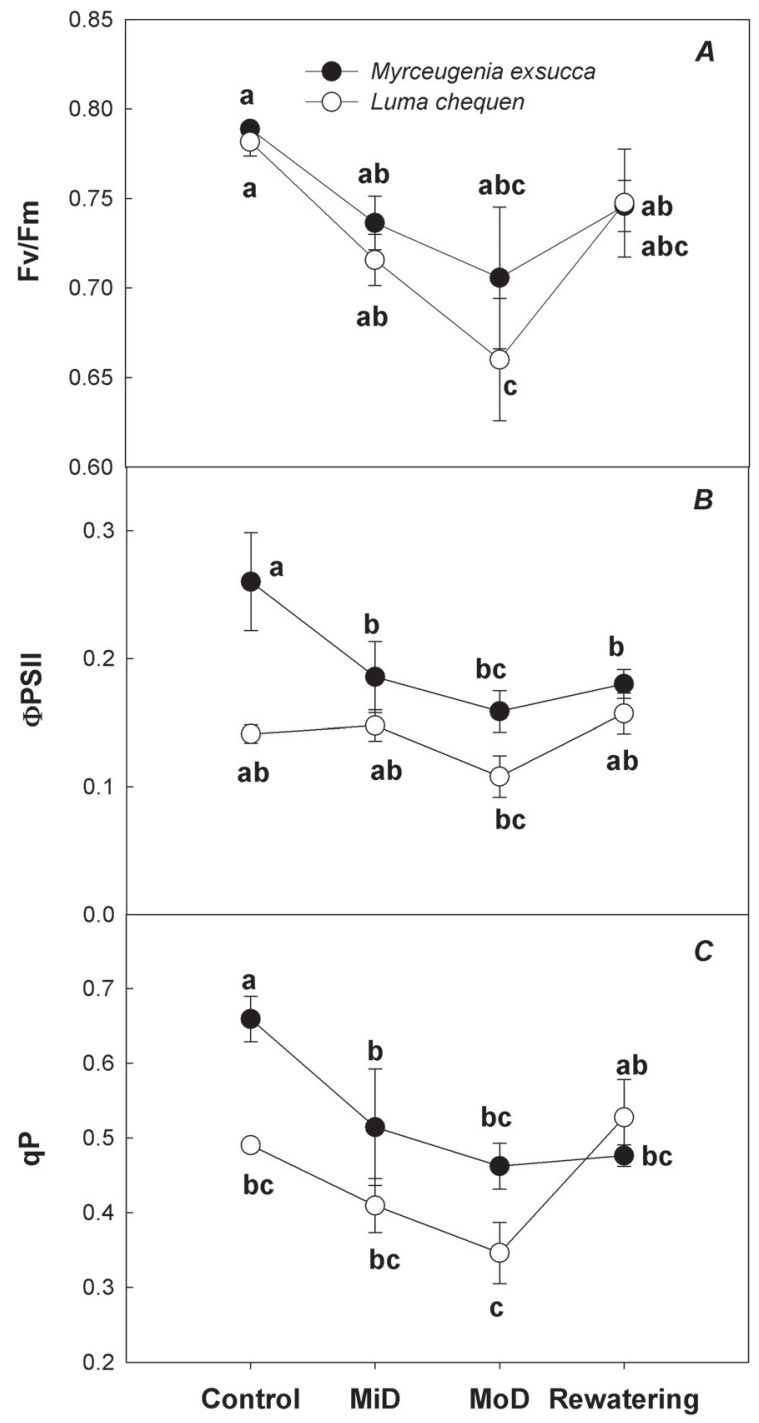

Figure 2. (A) Maximal photochemical efficiency (Fv/Fm), (B) quantum yield of PSII (ФPSII) and (C) photochemical quenching (qP) under different irrigation treatments. Control, mild drought (MiD), moderate drought (MoD) and re-watering. Measurements were done at room temperature using an actinic light of 300 $\mu$ moles of photons $\mathrm{m}^{-2} \mathrm{~s}^{-1}$. Values represent mean \pm standard error of six replicates. Different letters denote statistical differences by Dunnett test $(\mathrm{P}<0.05)$ among treatments and species.

Figura 2. (A) Eficiencia fotoquímica máxima (Fv/Fm), (B) rendimiento cuántico del PSII (ФPSII) y (C) el apagamiento fotoquímico (qP) bajo diferentes tratamientos de riego. Control, sequía leve (MID), sequía moderada (MoD) y re-hidratación. Las mediciones se realizaron a temperatura ambiente usando una luz actínica de 300 moles de fotones $\mathrm{m}^{-2} \mathrm{~s}^{-1}$. Los valores representan el promedio \pm error estándar de seis repeticiones. Letras diferentes indican diferencias estadísticas según la prueba de Dunnett ( $P$ $<0,05)$ entre los tratamientos y las especies. 
to species $\left(\mathrm{F}_{1,40}=7.68, \mathrm{P}=0.008\right)$, treatment $\left(\mathrm{F}_{3,37}=4.21\right.$, $\mathrm{P}=0.012)$, and the interaction of species and treatment $\left(\mathrm{F}_{3,34}=4.77, \mathrm{P}=0.007\right)$. qP was $25 \%$ higher in $M$. exsucca than in $L$. chequen. $\mathrm{MiD}$ caused a significant decline in $\mathrm{qP}$ for $M$. exsucca to values comparable to those for L. chequen (Fig. 2C). After re-watering L. chequen exhibited a statistical increase in qP compared to MoD treated plants, with values similar to those for control plants, while qP levels for $M$. exsucca were lower than initial values.

NPQ was affected statistically by species $\left(\mathrm{F}_{1,40}=4.41\right.$, $\mathrm{P}=0.04)$, treatment $\left(\mathrm{F}_{1,37}=4.44, \mathrm{P}=0.009\right)$, and the interaction of species and treatment $\left(\mathrm{F}_{3,34}=4.29, \mathrm{P}=\right.$ 0.01). Both species exhibited similar NPQ values under control conditions, MiD, and after re-watering (Fig. 3). Under MoD, NPQ values for $L$. chequen increased by $20 \%$. This response was related to a significant increase in $\mathrm{NPQ}_{\mathrm{f}}\left(\mathrm{F}_{3,37}=4.76, \mathrm{P}=0.007\right)$ without changes in $\mathrm{NPQ}_{\mathrm{s}}$. Twenty-four hours after re-watering, the NPQ levels for L. chequen returned to levels similar to controls. A strong correlation between $\Psi_{w}$ and $\mathrm{qP}\left(\mathrm{r}^{2}=0.77, \mathrm{P}=0.007\right)$ and a weaker relationship between $\Psi_{w}$ and NPQ were observed in both species $\left(r^{2}=0.22\right)$ (Fig. 4). Changes in the amount of chlorophyll, carotenoids and xanthophylls $(\mathrm{C}+\mathrm{x})$, and total soluble sugars in response to mild and moderate drought conditions and re-watering were not observed. Under control conditions $M$. exsucca contained more chlorophyll $a\left(\mathrm{~F}_{1,30}=63.2, \mathrm{P}<0.001\right)$ and chlorophyll $a+b\left(\mathrm{~F}_{1,30}=28.03, \mathrm{P}<0.001\right)$ and had a higher $\mathrm{Chl} a / \mathrm{Chl} b$ ratio $\left(\mathrm{F}_{1,30}=35.28, \mathrm{P}<0.001\right)$ than $L$. chequen (Table II). Nevertheless, non- statistical differences in response to drought or re-watering were observed between species for chlorophyll $a$ and chlorophyll $a+b$ content and the Chl $a$ / $\mathrm{Chl} b$ ratio $(\mathrm{P}>0.05)$. Under control conditions, the amount of chlorophyll $b$ was higher in $L$. chequen than in $M$. exsucca. During drought treatments, chlorophyll $b$ tended to decrease in L. chequen. However, significant reductions were only observed after re-watering (Table II). No change in chlorophyll $a$ and the reduction of chlorophyll $b$ content in $L$. chequen was reflected in a significant increase in the $\mathrm{Chl} a / \mathrm{Chl} b$ ratio under $\mathrm{MoD}$ and re-watering conditions $\left(\mathrm{F}_{3.24}=37.2, \mathrm{P}<0.01\right)$. No statistical differences in either species or treatments were observed in the $\mathrm{C}+\mathrm{x}$ content or the $\mathrm{Chl} / \mathrm{C}+\mathrm{x}$ ratio.

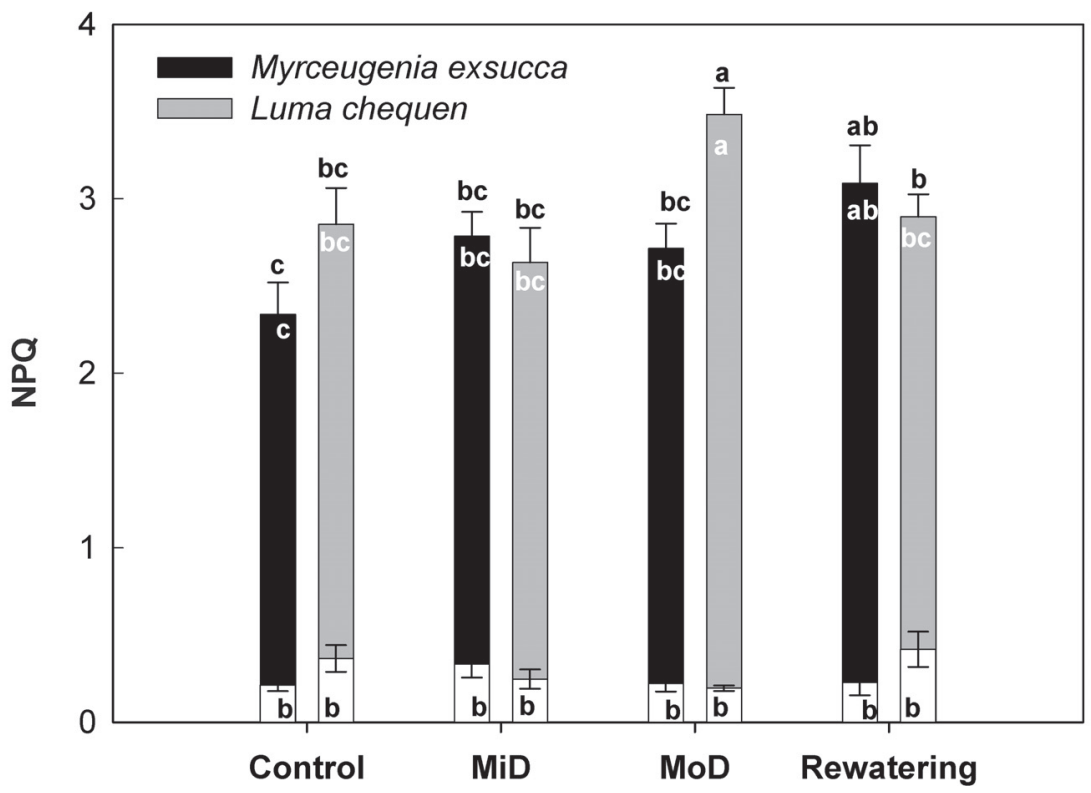

FIGURE 3. Total and individual components of non-photochemical quenching under different irrigation treatments. Control, mild drought $(\mathrm{MiD})$, moderate drought $(\mathrm{MoD})$ and re-watering. Measurements were done at room temperature using an actinic light of $300 \mu \mathrm{moles}$ of photons $\mathrm{m}^{-2} \mathrm{~s}^{-1}$. Bars represent total NPQ, and the top and the bottom bars represent the components of $\mathrm{NPQ}_{\mathrm{NPQ}}\left(\mathrm{N}_{\mathrm{f}}\left(\mathrm{colored}\right.\right.$ bars) and $\mathrm{NPQ}_{\mathrm{s}}$ (white bars). Bars show mean values \pm SE. Different letters denote statistical differences by Dunnett test $(\mathrm{P}<0.05)$ among treatments and species.

Figura 3. Componentes totales e individuales del apagamiento no fotoquímica de los diferentes tratamientos de riego experimentados. Control, sequía leve (MID), sequía moderada (MoD) y re-hidratación. Las mediciones se realizaron a temperatura ambiente usando una luz actínica de 300 moles de fotones $\mathrm{m}^{-2} \mathrm{~s}^{-1}$. Las barras representan el total de NPQ, y las barras superior e inferior representan los componentes $\mathrm{NPQ}: \mathrm{NPQ}_{\mathrm{f}}$ (barras de color) y $\mathrm{NPQ}_{\mathrm{s}}$ (barras blancas). Las barras muestran los promedios $\pm \mathrm{SE}$. Letras diferentes indican diferencias estadísticas según la prueba de Dunnett $(\mathrm{P}<0,05)$ entre los tratamientos y las especies. 
TABLE II. Effect of progressive drought and re-watering on chlorophyll content ( $\mu \mathrm{g} \mathrm{g}^{-1} \mathrm{FW}$ ), carotenoids ( $\mu \mathrm{g} \mathrm{g} \mathrm{g}^{-1} \mathrm{FW}$ ) on $M$. exsucca and $L$. chequen. Results show mean values $\pm \mathrm{SE}$ of 4 replicates. Different letters represent significant differences between treatment and species $\mathrm{P}<0.05$ using Dunnett test.

TABLA II. Efecto de la sequía progresiva y rehidratación en el contenido de clorofila ( $\left.\mathrm{mg} \mathrm{g}^{-1} \mathrm{FW}\right)$, carotenoides (mg g-1 $\mathrm{FW}$ ) sobre $M$. exsucca y L. chequen. Los resultados muestran valores promedios $\pm \mathrm{SE}$ de 4 repeticiones. Letras distintas representan diferencias significativas entre el tratamiento y la especie $\mathrm{P}<0,05$ utilizando la prueba de Dunnett.

\begin{tabular}{|c|c|c|c|c|c|c|c|}
\hline & & Chl $a$ & Chl $b$ & Chl $a+\operatorname{Chl} b$ & Chl $a /$ Chl $b$ & $\mathrm{C}+\mathrm{x}$ & $\mathrm{Chl} / \mathrm{C}+\mathrm{x}$ \\
\hline \multirow[t]{4}{*}{ M. exsucca } & $\mathrm{C}$ & $443 \pm 35$ (a) & $66 \pm 8(b)$ & $509 \pm 35(\mathrm{ab})$ & $7.1 \pm 1.3$ (a) & $74 \pm 8(a)$ & $7 \pm 1$ (a) \\
\hline & MiD & $433 \pm 80$ (a) & $72 \pm 15(a b)$ & $505 \pm 94$ (a) & $6.1 \pm 0.6(\mathrm{abc})$ & $71 \pm 12$ (a) & $7.2 \pm 1$ (a) \\
\hline & MoD & $453 \pm 20$ (a) & $86 \pm 17(a b)$ & $539 \pm 37(\mathrm{ab})$ & $6.1 \pm 1.5(\mathrm{abc})$ & $68 \pm 6(a)$ & $8.2 \pm 1$ (a) \\
\hline & $\mathrm{Rw}$ & $430 \pm 37$ (a) & $83 \pm 13(a b)$ & $513 \pm 46(a b)$ & $5.4 \pm 0.8(\mathrm{ab})$ & $67 \pm 6(a)$ & $7.9 \pm 1(a)$ \\
\hline \multirow[t]{4}{*}{ L. chequen } & $\mathrm{C}$ & $273 \pm 26$ (b) & $147 \pm 31$ (a) & $420 \pm 51(a b)$ & $2.0 \pm 0.4(\mathrm{~d})$ & $73 \pm 14(a)$ & $6.3 \pm 1(a)$ \\
\hline & MiD & $276 \pm 24$ (b) & $104 \pm 20$ (a) & $379 \pm 40(b)$ & $2.8 \pm 0.26(\mathrm{dc})$ & $43 \pm 12$ (a) & $9.9 \pm 2$ (a) \\
\hline & MoD & $240 \pm 20(b)$ & $79 \pm 7(a b)$ & $319 \pm 23$ (c) & $3.1 \pm 0.3$ (c) & $55 \pm 10$ (a) & $6.4 \pm 1$ (a) \\
\hline & Rw & $268 \pm 15$ (b) & $71 \pm 2(b)$ & $339 \pm 15$ (c) & $3.7 \pm 0.2(\mathrm{c})$ & $56 \pm 13(a)$ & $7 \pm 1$ (a) \\
\hline
\end{tabular}

\section{DISCUSSION}

Myrceugenia exsucca and Luma chequen are two evergreen species from the Myrtaceae family with fulfill important ecological functions (Correa-Araneda et al. 2011, Solervicens \& Elgueta 1994, Villagrán \& Hinojoza 1997). Considering the destruction of their natural habitat and the possibility of their conservation under lower moisture soils conditions is important to accurate the drought tolerance and the capability of recovery after a drought episode.

Our principals results shows that $L$. chequen was not affected by MiD suggesting that it was able to maintain, or quickly adjust its water status under mild drought. In contrast, the water status and the photochemical level of $M$. exsucca was affected by both $\mathrm{MiD}$ and $\mathrm{MoD}$ indicating a higher sensitivity of this species to water scarcity. The better water status of $L$. chequen could be associated with a lower leaf area as compared to $M$. exsucca (Table I), which could reduce the transpirational surface and water loss (Sanhueza et al. 2014, Liu et al. 2011). The leaf area reduction is an important strategy to cope with drought in the wetland plant Phragmites australis (Pagter et al. 2005).

M. exsucca displayed a larger amount of $\mathrm{Chl} a$ with respect to L. chequen, which is reflected in a higher $\mathrm{Chl}$ $a / \mathrm{Chl} b$ ratio. Considering that the core complex of PSII has mainly Chl $a$, and the antenna complex has both Chl $a$ and $b$, a higher ratio of $\mathrm{Chl} a / \mathrm{Chl} b$ may indicate a decrease in light capture in relation to rates of PSII photochemistry (Demmig-Adams and Adams, 1996). In fact, the ability of electron transport chain to maintain PSII reaction centers in open state (qP) under control conditions was significantly higher in M. exsucca than in L. chequen. This could be related with the lower specific leaf area of $M$. exsucca, respect to L. chequen which could involve a higher density of PS and a higher probability of photochemicals process in the same area (Vile et al. 2005, He et al. 2013). Drought reduction in pigment content has been considered a typical symptom of oxidative stress, as a result of either slow synthesis or fast breakdown (Christ et al. 2014).

Maintenance of chlorophyll content and Fv/Fm during drought treatment in $M$. exsucca may indicate no significant perturbation of maximal PSII efficiency by oxidative damage which has been also reported in species of Nothofagus (Sanhueza et al. 2013). However, in many plants, Fv/Fm is insensitive to reduction in photosynthetic electron transport under drought conditions, and seems to be more associated to Chl variations (Llorens et al. 2004, Christ et al. 2014). A tendency to decreased $\mathrm{Chl} b$ under MoD was observed in $L$. chequen, such as Chl $a$ content was stable during drought, a significant increase in the $\mathrm{Chl} a / \mathrm{Chl} b$ ratio was observed. This could be related with the reduction of Fv/Fm by $10 \%$, likely as a consequence of reduced photochemical efficiency of PSII. These responses were related with an increment of NPQ, without an increase in photoinhibitory components (NPQs) under MoD. The increment of NPQ for $L$. chequen under drought was reported previously (Bascuñán-Godoy et al. 2013) and the present results are indicating that NPQ could be a protective strategy to dissipate excessive energy which could be explained as a decrease of peripheral light-harvesting complexes (Krause 1988, Osmond 1994). These changes were not accompanied by changes in $\mathrm{C}+\mathrm{X}$ content, but might be related with the conversion of pigments in the xanthophylls cycle (DemmigAdams et al. 1996). The increase of NPQ in L. chequen was not related with an increase in the amount of carotenoid and xantophylls or changes in the $\mathrm{Chl} / \mathrm{C}+\mathrm{x}$ ratio. Furthermore, under these light conditions $\left(300 \mu \mathrm{mol} \mathrm{m}^{-2} \mathrm{~s}^{-1}\right)$ it is unlikely that these plants suffer photodamage to considerably reduce 
the $\mathrm{Fv} / \mathrm{Fm}$, although, photoinhibition such as a decrease in photochemistry does occur. In fact, under MiD, M. exsucca experienced a significant photochemistry capacity decrease shown by the important reduction of ФPSII and qP. It is suggested that levels of $\Phi$ PSII and $\mathrm{qP}$ achieved by $M$. exsucca under drought conditions could be the consequence of stressful conditions for this species. Interestingly, despite the strong decrease in $\mathrm{qP}$ and ФPSII, $M$. exsucca was not able to increase thermal dissipation. This is consistent with the observation of Savage et al. (2009), who suggested that an increase of thermal dissipation is not a strategy used by wetland specialist plants under drought, possibly due to xanthophylls de-epoxidation failure. Another explication is that under the experimental light conditions are not high enough to induce increase of NPQ under these experimental conditions. The results indicate that $L$. chequen is able to reestablish both water status and functional capacity (observed by the total recovery of $\mathrm{Fv} / \mathrm{Fm}$ and $\mathrm{qP}$ ). It is suggested that the significant increase of several soluble sugars provide an effective mechanism to maintain sufficient turgor for stomatal re-opening and return the photosynthetic productivity (Galiano et al. 2011). In this context the $60 \%$ of increase in soluble sugars experienced by $L$. chequen (Fig.1C) could be seen not only as the product of enhanced of photosynthesis capacity, but also as a mechanism to return to cellular homeostasis and functionality after stress relief. It is known that carbon reserves are essential to maintain both carbon and nitrogen balance under drought conditions, which are the principal physiological impairments related with tree death under water scarcity (Allen et al. 2010). It is seems that the higher content of soluble sugars of $L$. chequen could be involved in the better functionality of photochemical and photosynthetic performance under drought stress relief conditions.

On the other hand, M. exsucca was unable to reestablish ФPSII and qP after rewatering. This may be related with only a partial recovery of $\Psi_{w}$ which could be affecting the stomatal conductance and photosynthetic capacity (Sanhueza et al. 2013, 2014, Chaves et al. 2009, Flexas \& Medrano 2002). The strong relationship between $\mathrm{qP}$ and $\Psi_{\mathrm{w}}\left(\mathrm{r}^{2}=0.77\right)$ (Fig. $4 \mathrm{~A})$ suggests a greater dependence on stomatal conductance and water status for photochemical performance. In this sense, it is suggested that qP maintenance could be a general functional indicator of physiological performance under drought stress (He et al. 2013).

It was observed that $M$. exsucca individuals experienced leaf abscission after 30 days of drought under laboratory conditions. There is evidence that photoinhibition plays a role in senescence and leaf abscission, which is triggered by hormonal signals to prevent water loss (Chaves et al. 2002, Pinheiro \& Chaves 2011). Considering the impairment of the physiological performance of M. exsucca and its leaf abscission under drought, together with the fact that the flowering (which is the more drought sensitivity phenological stage of plants) is extended to months when water availability increase (Villagrán 1982), we could suggest that this species experience avoidance as principal drought resistance strategy. Considering that $M$. exsucca is a vulnerable species, prolonged studies are necessary to better understand of strategies and thresholds for drought resistance in this species.

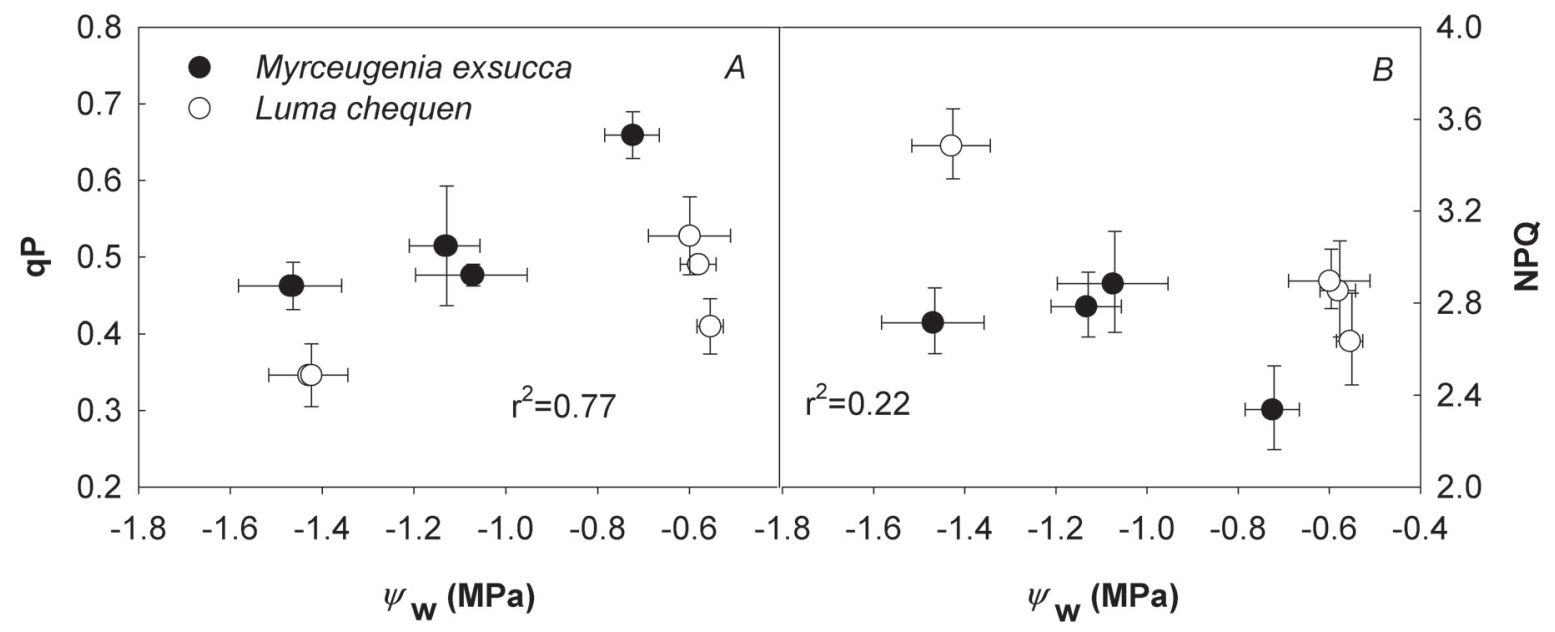

FIGURE 4. Relationship between photochemical quenching (qP) (A) and Non-photochemical quenching (NPQ) (B) with water potential $\left(\Psi_{\mathrm{w}}\right)$ for the four treatments studied. Filled circles $(\bullet)$ and empty circles $(\circ)$ correspond to Myrceugenia exsucca and Luma chequen, respectively. Mean values $\pm \mathrm{SE}$ were calculated from five independent measurements from five different plants.

FIGURA 4. Relación entre el apagamiento fotoquímico (qP) (A) y el apagamiento no fotoquímico (NPQ) (B) con el potencial hídrico ( $\left.\Psi_{w}\right)$ para los cuatro tratamientos estudiados. Los símbolos en negro (•) y los círculos vacíos ( $\mathrm{O}$ ) corresponden a Myrceugenia exsucca y Luma chequen, respectivamente. Los promedios $\pm \mathrm{SE}$ fueron calculados a partir de cinco mediciones independientes de cinco plantas diferentes. 
In summary, we found that $L$. chequen displays physiological mechanisms to maintain its water status and normal function of photochemical processes under low water availability. In addition, $L$. chequen exhibits a great capacity to recover photochemical activity after re- watering. In contrast, $M$. exsucca, which was related with avoidance mechanisms, loses water easily with a lower capacity of osmotic adjustment than $L$. chequen, and decreased their photochemical processes without experiencing fast recovery under favorable water conditions.

In conclusion, our findings suggest that L. chequen seems to be more able to withstand increased soil drought than $M$. exsucca not only for a higher drought tolerance further by a strong recovery capability. These results are in agreement with its water gradient distribution and are important for the design of mitigation strategies and in selecting suitable species to include in projects aimed at restoring degraded habitats and creating new ones.

\section{ACKNOWLEDGMENTS}

LBG thanks to Fondecyt 11130480 for supporting this work and A. M. to FONDECYT 11070016 for project funding. D. C. is grateful to CONICYT for doctoral fellowship (21140050).

\section{REFERENCES}

Aceituno, P. 1988. On the functioning of the southern oscillation in the South American sector. Part I: Surface climate. Monthly Weather Review 116: 505-524

Allen, C.D., A.K. Macalady, H. Chenchouni, D. Bachelet, N. McDowell, M. Vennetier, T. Kitzberger, A. Rigling, D.D. Breshears, E.H. Hogg, P. Gonzalez, R. Fensham, Z. Zhang, J. Castro, N. Demidova, J.H. Lim, G. Allard, S.W. Running, A. Semerci, \& N. Cobb. 2010. A global overview of drought and heat-induced tree mortality reveals emerging climate change risks for forests. Forest Ecology and Management 259: 660-684.

Arancio, G., M. Muñoz-Schick \& F.A. Squeo. 2001. Estado de conservación de la flora nativa de la Región de Coquimbo. En: F.A. Squeo, G. Arancio \& J.R. Gutiérrez (eds.). Libro Rojo de la flora nativa y los sitios prioritarios para su conservación, Región de Coquimbo, pp. 63-103. Ediciones Universidad de La Serena, La Serena, Chile.

Bascuñán-Godoy, L., C. Alcaino, D.E. Carvajal, C. Sanhueza \& A. Maldonado. 2013. Different photoprotective responses under drought conditions of two predominant chilean swamp forest species. Gayana Botanica 70(2): 279-286

Busch, D.E. \& S.D. Sмiтh. 1995. Mechanisms associated with decline of woody species in riparian ecosystems of the Southwestern U.S. Ecological Monographs 65: 347-370.

Chaves, M.M., J. Flexas \& C. Pinheiro. 2009. Photosynthesis under drought and salt stress: regulation mechanisms from whole plant to cell. Annals of Botany 103: 551-560.
Chaves, M., J.S. Pereira, J. Maroco, M.L. Rodrigues, C.P.P. Ricardo, M.L. Osório, I. Carvalho, T. Faria \& C. PINHEIRO. 2002. How plants cope with water stress in the field? Photosynthesis and growth. Annals of Botany 89: 907-916.

Christ, B., A. Egert, I. Süssenbacher, B. Kräutler, D. Bartels, S. Peters \& S. Hörtensteiner. 2014. Water deficit induces chlorophyll degradation via the 'PAO/phyllobilin' pathway in leaves of homoio- (Craterostigma pumilum) and poikilochlorophyllous (Xerophyta viscosa) resurrection plants. Plant, Cell \& Environment 37: 2521-2531.

Correa-Araneda, F., J. Urrutia \& R. Figueroa. 2011. Estado del conocimiento y principales amenazas de los humedales boscosos de agua dulce de Chile. Revista Chilena de Historia Natural 84: 325-340.

Correa-Araneda, F.J., J. Urrutia, Y. Soto-Mora, R. Figueroa \& E. Hauenstein. 2012. Effects of the hydroperiod on the vegetative and community structure of freshwater forested wetlands, Chile. Journal of Freshwater Ecology 27: 459470.

Demmig-Adams, B. \& W.W. Adams. 1992. Photoprotection and other responses of plants to high light stress. Annual Review of Plant Physiology and Plant Molecular Biology 43: 599-626.

Demmig-Adams, B., A.M. Gilmore \& W.W. Adams. 1996. In vivo functions of carotenoids in higher plants. The FASEB Journal 10: 403-412.

Donoso, C. 2006. Las Especies arbóreas de los bosques templados de Chile y Argentina: Autoecología. Marisa. Cuneo Ediciones, Valdivia, Chile. 678 pp.

Flexas, J. \& H. Medrano. 2002. Drought-inhibition of photosynthesis in C3 plants:stomatal and non-stomatal limitations revisited. Annals of Botany 89: 183-189.

Galiano, L., J. Martínez-Vilalta \& F. Lloret. 2011. Carbon reserves and canopy defoliation determine the recovery of Scots pine 4 yr after a drought episode. New Phytologist 190: 750-759.

GonzÁlez, M.E., A. Lara, R. Urrutia \& J. Bosnich. 2011. Climatic change and its potential impact on forest fire occurrence in south-central Chile $\left(33^{\circ}-42^{\circ} \mathrm{S}\right)$. Bosque 32(3): 215-219.

He, J., H. Norhafis \& L. QIN. 2013. Responses of green leaves and green pseudobulbs of CAM orchid Cattleya laeliocattleya Aloha case to drought stress. Journal of Botany, Article ID 710539, 9 pp.

Hu, W.H., Y.A. XIAO, J.J. Zeng \& X.H. Hu. 2010. Photosynthesis, respiration and antioxidant enzymes in pepper leaves under drought and heat stresses. Biologia Plantarum 54: 761-765.

Krause, G.H. 1988. Photoinhibition of photosynthesis. An evaluation of damaging and protective mechanisms. Physiologia Plantarum 74: 566-74.

Landrum, L.R. 1988. The Myrtle Family (Myrtaceae) in Chile. Proceedings California Academy of Sciences 45: 277-317.

Lauteri, M., M. Haworth, R. Serraj, M.C. Monteverdi \& M. CEnTritto. 2014. Photosynthetic diffusional constraints affect yield in drought stressed rice cultivars during flowering. PLoS ONE 9(10): e109054.

Lichtenthaler, H.K. 1987. Chlorophylls and carotenoids: pigments of photosynthetic biomembranes. Methods in Enzymology 148: 350-382. 
Liu, C., Y. Liu, K. Guo, D. Fan, G. Li, Y. Zheng, L. Yu \& R. Yang. 2011. Effect of drought on pigments, osmotic adjustment and antioxidant enzymes in six woody plant species in karst habitats of southwestern China. Environmental and Experimental Botany 71: 174-183.

Llorens L., J. Peñuelas, C. Beier, B. Emmett, M. Estiarte \& A. Tietema. 2004. Effects of an experimental increase of temperature and drought on the photosynthetic performance of two Ericaceous shrub species along a North-South European gradient. Ecosystems 7: 613-624.

Maldonado, A. \& C. Villagrán. 2001. Historia del bosque pantanoso de Ñague, costa de Los Vilos (IV Región, Chile) y sus relaciones con los cambios paleoambientales de los últimos 5.300 años A.P. En: F.A. Squeo, G. Arancio \& J.R. Gutiérrez (eds.), Libro Rojo de la flora nativa y los sitios prioritarios para su conservación, Región de Coquimbo: 261-273. Ediciones Universidad de La Serena, La Serena, Chile.

Maxwell, K. \& G.N. Johnson. 2000. Chlorophyll fluorescence a practical guide. Journal of Experimental Botany 51: 659668.

Mielke, M.S. \& B. Schaffer. 2010. Photosynthetic and growth responses of Eugenia uniflora L. seedlings to soil flooding and light intensity. Environmental and Experimental Botany 68: 113-121.

Nakai, A., Y. Yurugi \& H. Kisanuki. 2010. Stress responses in Salix gracilistyla cuttings subjected to repetitive alternate flooding and drought. Trees-Structure and Function 24: 1087-1095.

Nishiyama, Y., S.I. Allakhverdiev \& N. Murata. 2011. Protein synthesis is the primary target of reactive oxygen species in the photoinhibition of photosystem II. Physiologia Plantarum 142: 35-46.

Osmond, C.B. 1994. What is photoinhibition? Some insights from comparisons of shade and sun plants. In: N.R. Baker \& J.R. Bowyer (eds.), Photoinhibition of photosynthesis. From molecular mechanisms to the field, pp. 1-24. BIOS Scientific Publishers Limited-Oxford.

Pagter, M., C. Bragato \& H. Brix. 2005. Tolerance and physiological responses of Phragmites australis to water deficit. Aquatic Botany 81: 285-299.

Peguero-Pina, J.J., D. Sancho-Knapik, F. Morales, J. Flexas \& E. Gil-Pelegrin. 2009. Differential photosynthetic performance and photoprotection mechanisms of three Mediterranean evergreen oaks under severe drought stress. Functional Plant Biology 36: 453-462.

Pinheiro, C. \& M.M. Chaves. 2011. Photosynthesis and drought: can we make metabolic connections from available data. Journal of Experimental Botany 62: 869-882.

Ramírez, C., F. Ferriere \& H. Figueroa. 1983. Estudio fitosociológico de los bosques pantanosos templados del sur de Chile. Revista Chilena de Historia Natural 56:11-26.

Ramírez, C., C. SAn Martín \& J. SAn Martín. 1995. Estructura florística de los bosques pantanosos de Chile sur-central. En: J.J. Armesto, C. Villagrán \& M.T.K. Arroyo (eds.), Ecología del bosque nativo de Chile, pp. 215-234. Editorial Universitaria, Santiago, Chile.

Roe, J.H. 1934. A colorimetric method for the determination of fructose in blood and urine. The Journal of Biological Chemistry 107: 15-22.

Sanhueza, C., L. Bascuñán-Godoy, L.J. Corcuera, M.H. TURnBull. 2013. The response of leaf respiration to water stress in Nothofagus species. New Zealand Journal of Botany 51: 88-103.

Sanhueza, C., L. Bascuñán-Godoy, M.H. Turnbull \& L.J. Corcuera. 2014. Response of photosynthesis and respiration to temperature under water deficit in two evergreen Nothofagus species. Plant Species Biology doi: 10.1111/1442-1984.12047.

San Martín, J., A. Troncoso \& C. Ramírez. 1988. Estudio fitosociológico de los bosques pantanosos nativos de la cordillera de la Costa central. Bosque 9: 17-33.

Savage, J.A., J. Cavender-Bares \& A. Verhoeven. 2009. Willow species (genus: Salix) with contrasting habitat affinities differ in their photoprotective responses to water stress. Functional Plant Biology 36: 300-309.

Schreiber, U., W. Schliwa \& U. Bilger. 1986. Continuous recording of photochemical and non-photochemical chlorophyll fluorescence quenching with a new type of modulation fluorometer. Photosynthesis Research 10: 5162.

Solervicens, J. \& M. Elgueta. 1994. Insectos de follaje de bosques pantanosos del Norte Chico, Centro y Sur de Chile. Revista Chilena de Entomología 21: 135-164.

Vile, D., E. Garnier, B. Shipley, G. Laurent, Ml. Navas, C. Roumet, S. Lavorel, S. Díaz, J.G. Hodgson, F. Lloret, G.F. Midgley, H. Porter, M.C. Rutherford, P.J. Wilson \& I.J. WRIGHT. 2005. Specific leaf area and dry matter content estimate thickness in laminar leaves. Annals of Botany 96: 1129-1136.

VillagRÁn, C. 1982. Floristic structure and history of the swamp forest of Quintero (Chile, V Region) and its relationship with relict communities of north-central of Chile. Geological Congress Acta 3: 377-402.

Villagrán, C. \& L.F. Hinojosa. 1997. History of the forests of southern South America, Phytogeographical Analysis. Revista Chilena de Historia Natural 70: 241-267.

Walters, R.G. \& P. Horton. 1991. Resolution of components of non-photochemical chlorophyll fluorescence quenching in barley leaves. Photosynthesis Research 27: 121-133.

Recibido: 05.01.15

Aceptado: 03.07.15 